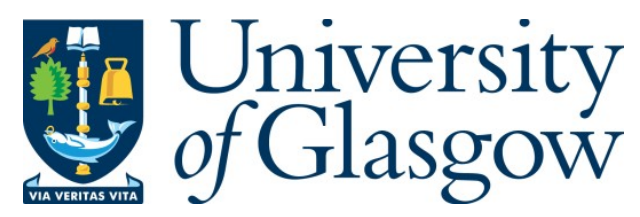

Souleimanov, E. A. and Aliyev, H. (2020) Ideology and disengagement: a case study of nationalists and Islamists in Chechnya. Europe-Asia Studies, 72(2), pp. 314-330.

(doi: $10.1080 / 09668136.2019 .1694864)$

There may be differences between this version and the published version. You are advised to consult the publisher's version if you wish to cite from it.

https://eprints.gla.ac.uk/177630/

Deposited on: 11 January 2019

Enlighten - Research publications by members of the University of Glasgow http://eprints.gla.ac.uk 


\title{
Ideology and Disengagement: A Case Study of Nationalists and Islamists in Chechnya
}

\author{
Emil A. Souleimanov and Huseyn Aliyev \\ Charles University Prague \\ University of Glasgow
}

Accepted for publication in Europe-Asia Studies

Abstract: Disengagement from militant groups has often been related to individual level explanations like battle fatigue or desire to re-join family and friends. We seek to empirically examine which other factors, beyond individual level determinants, influenced disengagement processes among militants belonging to different types of Chechen militant organizations. Drawing empirical insights from unique in-depth interviews with former members of Chechen insurgency, their relatives, eyewitnesses of Chechen wars, and experts with first-hand knowledge of the researched phenomena, this study examines disengagement among jihadist and nationalist Chechen militants. Focusing on group-level factors, such as capacity to resist external pressures, use of violence, in-group social bonds and group cohesion, this article demonstrates that disengagement was a less viable course of action for Chechen jihadists than for nationalist militants. 
This article seeks to examine pathways towards group-level disengagement ${ }^{1}$ from militant organizations among two types of militants in Russia's republic of Chechnya: nationalists and jihadists. Existing research on militant disengagement has mostly focused on individual-level characteristics as determinants of disengagement (Altier et al. 2014). Scholars demonstrated that members of militant groups can be more or less receptive to push and pull factors. They may be pushed from their respective groups by disillusionment with ideology, disapproval of military tactics and mistrust in their comrades (Oppenheim et al. 2015; McLauchlin 2015), or pulled from the outside by external pressure, demobilization incentives and a desire to return to family and friends (Bearman 1991; Horgan 2009; Walter 1999). In this article, we extend our analysis beyond individual-level determinants in that we empirically examine what role does the type of militant organization play in the process of disengagement for its members, focusing on Chechen nationalist and Islamist ${ }^{2}$ militants. In contrast to research on individual-level factors, we explore whether such group-level determinants as external pressure, use of violence, social bonds and group cohesion affected individual choices to leave armed groups during the

1 Due to the absence of an all-encompassing definition of group-level disengagement that could be applied to broader categories of militants beyond 'terrorists' and 'freedom fighters', this study endorses the conceptualization of disengagement as a generic term. In this vein, disengagement is presented here as the process through which members of militant organizations abandon their groups. This definition does not exclude the possibility of disengagement occurring as part of a broader process of demobilization, such as following amnesties or demobilization programs or within the framework of peace-building and rehabilitation processes. Also, it leaves the question of psychological de-radicalization open (Doosje et al. 2016). In fact, individuals might disengage without ever de-radicalizing (Altier et al. 2014, 648).

2 The terms Islamists and jihadists are used interchangeably. 
First Chechnya War (1994-1996) and the Second Chechnya War (1999-). More specifically, we aim to examine differences in disengagement pathways between nationalist and Islamist groups.

It has been argued in the literature that while nationalists seek self-determination and tend to use ideology instrumentally for the achievement of this goal, Islamists have higher levels of commitment to the absolute values of their organization and their behaviour is thus not reducible to instrumental reasoning (Gutiérrez and Wood 2014; Hegghammer 2009; Piazza 2009). ${ }^{3}$ Scholars proposed that difference in the type of ideology and a higher degree of exposure to ideological indoctrination among Islamists is key for the process of individual disengagement. It affects the militants' capacity to resist external pressure, their patterns of use of violence, and their social bonds with local communities and group cohesiveness. A comparative focus on Chechen nationalists and Islamists enables researchers to identify how substantive differences in the ideologies of militant organizations affect group-level disengagement, an aspect that has not been sufficiently recognized in existing research. Since the end of the First Chechen War in 1996, Chechnya's once-dominant nationalist forces began to morph into an Islamist movement, which eventually replaced in 2007 the initially nationalist-inspired Chechen Republic of Ichkeria with the Salafi-inspired Caucasus Emirate (Hughes 2007; Russell 2009). This transformation has been accompanied by large-scale, albeit generally individualized, disengagement and 're-qualification' of former nationalist fighters. While

3 This is particularly relevant for absolutist or universal Islamist groups, described by Piazza (2009), who pursue global jihad, as opposed to strategic or instrumental Islamists seeking other goals alongside religious motivation (independence, ethnic rights, etc.). 
some former nationalists abandoned armed struggle altogether, many others decided to join jihadist groups. Only a segment of nationalists remained in insurgent groups in which nationalist motivation has persisted, albeit masked by these groups' increasingly visible jihadist symbolic and rhetoric (Souleimanov 2014b).

Despite the existence of a rich body of literature on the Islamization of the Chechen insurgency (Hahn 2008; Souleimanov 2011; Sagramoso 2012), micro-level empirical analyses of how and why individual militants disengaged are notoriously rare (Souleimanov and Aliyev 2014). ${ }^{4}$ Drawing empirical insights from unique in-depth interviews with former members of Chechen militant groups, their relatives, eyewitnesses of the First and the Second Chechnya Wars, and experts, this study seeks to explore what effect does the ideology have on militants' choices concerning disengagement over the course of the two subsequent Chechen wars.

\section{Causes of disengagement}

${ }^{4}$ Thematically and theoretically, this study builds up on research published in Souleimanov and Aliyev (2014) book. However, the current study substantially differs from the book (which investigates individual disengagement) because it focuses exclusively on the group-level disengagement. In contrast to Souleimanov and Aliyev (2014) book, which covers a broad group of militants divided into nationalists, avengers and Islamists, this article has particular focus on the armed group's ideology. We specifically examine two types of militant organisations: nationalist and Islamist. The article presents more empirically rich analysis supported by 19 extra interviews with experts. In addition, 22 additional interviews were carried out with eye-witnesses of the Chechen wars. All these new interviews provide more nuanced and contextualized insights into the issue of group-level disengagement. Lastly, the 2014 book focuses on both Chechnya and Dagestan, whereas this article covers only Chechnya. The empirical analysis conducted in the article compares the First and Second Chechen Wars, which is fundamentally different from the empirical analysis of the book, which was focused on the broader North Caucasus insurgency. 
In our analysis of militant disengagement, we focus on nationalist and Islamist militants. We define as nationalist militant groups non-state armed groups that pursue some form of self-determination such as the creation of a nation-state with clearly defined physical borders (Cunningham 2014), as for example the Basque ETA, the Indonesia's Free Aceh Movement, and the Armed Forces of the Chechen Republic of Ichkeria (Alonso 2011; Horgan 2009; Souleimanov 2006). We define Islamist militant groups as non-state armed groups that seek, at least rhetorically, the establishment of an Islamic theocracy expanding across the Muslim world and who reject the nation-state and civil law (see Toft and Zhukov 2015, 223), such as for example the Islamic State and the Al-Nusra Front in Syria and Iraq, Boko Haram in Nigeria, or the various Salafi-jihadist organizations fighting in Chechnya (Hegghammer 2009; Souleimanov 2011). ${ }^{5}$ In their daily practice, nationalists receive generally less exposure to ideological indoctrination than Islamists (Hegghammer 2009). Indeed, while the degree of ideological exposure may vary across different nationalist groups and among individual militants belonging to those groups, it is generally perceived that militants belonging to these organizations have fairly weak ideological exposure (Piazza 2009). In contrast to nationalists, spiritual motives and the absolute importance of ideology are fundamental for Islamist militants (Piazza 2009). As documented in a number of studies (Hafez 2008; Alexander 2012; Hanasz 2012), jihadist militant groups, similarly to ethno-nationalist groups, generally attract large numbers of recruits, many (although not all) of whom initially lack detailed knowledge of religious

\footnotetext{
$5 \quad$ In some cases, nationalist and Islamist aspects may overlap in the same organization (for example the Palestinian Hamas). In other cases, there are alliances between nationalist and Islamist organizations (Christia 2012; Sinno 2009). The difference between these two types of organizations may thus be blurred in some contexts.
} 
texts or even sufficient familiarity with the organization's principal ideology. While the radical beliefs of some individuals may 'harden' as a result of their socialization within the Islamist organization and, especially, subject to state repression, the radicalization of views typically precedes joining the group (Doosje et al. 2016). After joining the organization, recruits motivated by jihadist ideology usually further undergo extensive and continuous indoctrination and exposure to the group's ideology, more so than members of nationalist groups (Nesser 2006; Hegghammer 2009).

Nationalists tend to invest in ideological training for instrumental purposes such as the achievement of self-determination, independence or autonomy from the state. Often they are capable of adapting their strategies under changing circumstances, for example, as a result of battle fatigue. For Islamists, religious dogmas, that form the base of their ideology, commit most of their members normatively and emotionally to certain patterns of behavior (Gutierrez and Wood 2014). ${ }^{6}$ The process which leads Islamist militants toward normative commitment is described in the literature as radicalization (Horgan 2009, Rabasa et al. 2010). Rabasa et al. $(2010,28)$ emphasize that "[a]lthough all kinds of militants may be fervent adherents to secular ideologies, religion provides a different type of motivation due to its promise that the devoted will receive an everlasting reward in the afterlife." Due to the promises of afterlife and the concept of intrinsic righteousness engrained in religious ideologies of militant Islamist groups, their recruits are relatively easier to radicalize than members of ethno-nationalist or 'secularly' motivated groups (Piazza 2009). In contrast to nationalist militants, Islamist militants are more willing to

6 There are exceptions to this presentation, as for example certain nationalists have used religion-like dogmas to produce doctrines of self-sacrifice much like the Islamist groups of today (Bartov 1992; Hall and Malešević 2013). 
sacrifice themselves and are willing to become martyrs (shahids) in the name of faith and divine purpose (Toft and Zhukov 2015). With the above in mind, we empirically examine how these two distinct types of Chechen militants pursued disengagement. We structure our empirical enquiry alongside four mechanisms of group-level disengagement: external pressure, use of violence, social bonds and group cohesiveness.

\section{Data and methods}

We examine the four aforementioned mechanisms on a case study of militants involved in the two subsequent armed conflicts in Chechnya. This context provides us with the simultaneous existence of nationalist and Islamist militants, which gives us the opportunity to compare across types of organizations that share similar background. As stated in the introduction, the Chechen conflict has become more and more "Islamized" over time, with Islamist organizations becoming more numerous over the years. External pressure on the government to encourage disengagement increased with the establishment of the kadyrovtsy counterinsurgent units which have systematically targeted militants' family members especially in the early 2000s (Souleimanov 2015a; see also Toft and Zhukov 2015, 228). Hence, with regards to external pressure, Islamists should have been exposed to disengagement pressure at least as heavily as nationalists. For the second and third mechanisms, we believe that the effect of time is less decisive.

This study draws primarily on interviews with three major categories of informants: (1) former insurgents; (2) their relatives, friends, neighbors and eyewitnesses; and (3) experts. Firstly, 28 unique in-depth semi-structured interviews with former Chechen 
insurgents were conducted between 2007 and $2015 .^{7}$ Of these interviewees, 23 were nationalists and five jihadists. The skewed sample is due to the fact that disengagement has been extremely rare among Chechen jihadists. In fact, there are no exact numbers of disengaged militants in Chechnya. According to Pavel Krasheninnikov, the former head of the legislative committee of the lower chamber of the Russian parliament, the State Duma, “... nobody [in federal authorities] checked the capitulation [of former insurgents]“" (Kavkaz Uzel 2006). In the absence of formal statistics about disengaged insurgents, available evidence from open sources and the informants consulted for this article coincide in that former insurgents who sought disengagement overwhelmingly belonged to the nationalist branch. ${ }^{8}$

Also, while nationalists and their families have left Chechnya en masse for the sake of survival, seeking political asylum in Turkey and European countries, jihadists have sought martyrdom on the battlefield, with their families remaining in Chechnya. Therefore, access to former nationalists was relatively easy given the authors' long-standing contacts with Chechen émigré communities in Europe and Turkey. By contrast, the task of identifying and locating former jihadists was much more difficult. Nevertheless, our pool of five former Chechen jihadists is unique in the literature to date. While these numbers do not constitute a representative sample, they nevertheless form one of the largest samples

$7 \quad$ We largely follow recommendations by Harris et al. $(2016,613)$ for the reporting of interview material.

$8 \quad$ For instance, Russian media reported the capitulation of dozens of nationalist insurgents in the period between 2003 and 2006, including such well-known insurgent commanders as Sulim Yamadaev, Magomed Khambiyev, Ruslan Israpilov, Ali Suleymanov and Sulim Eldarov. Even when prominent nationalist commanders refused to capitulate or disengage, many of their foot soldiers did, as was the case of the groups led by the nationalists Ruslan Gelayev, Aslan Maskhadov, and others. See RBK (2004), Kavkaz Uzel (2008), News.ru (2006) and Regnum (2003). 
available to date in the extant scholarship on the North Caucasus insurgency, and one of the few drawing on interview-based methods of inquiry. This is conditioned by the fact that conflict-related violence in the region-including in Chechnya-is ongoing, which considerably limits the accessibility of respondents.

Referral and snowballing techniques were used to gain access to informants from among former insurgents. The authors' long-term contacts with some key former insurgent and separatist leaders, ordinary insurgents, and reputed members of Chechen diaspora communities based in Europe and Turkey facilitated access to the ex-insurgents and ensured mutual trust between the researchers and interviewees. Due to security concerns, interviews were conducted outside Chechnya and Russia in various European and Turkish cities. For this same reason, all of the former insurgents consented to the interviews on the condition of strict confidentiality. Therefore, their names - and the exact locations of the interviews - are not disclosed in this article.

Interviews with former insurgents lasted from around three to six hours, with the average interview lasting around three and a half hours. In some occasions, interviews with two or more insurgents were conducted. The semi-structured interviews revolved around the central themes of disengagement, with questions moving from general to more narrowly formulated ones. This enabled the interviewees to develop their narratives in the most unrestricted way, leaving room for their own stories to unfold. Whenever possible, direct questions were avoided. ${ }^{9}$ Since the focus of our research was exclusively on

9 Interviews with former insurgents included, inter alia, these major questions: 'Why did you decide to leave your armed group?', 'Was your decision prompted by any event or process?', 'What forms did the pressure to stay in your armed group/to leave it take?"; What facilitated/complicated your return to peaceful life?", "What were your major concerns while leaving your group?", "During your time with your armed group, did you stay in touch with your community?" 
disengagement, we did not carry out interviews on causes of violent mobilisation and their relationship with disengagement.

The second batch of our interviewees $(n=27)$ includes the relatives of former nationalists (9) and of jihadists (5), the close friends of former nationalists (3) and of jihadists (4), as well as the former neighbors of nationalists (3) and jihadists (3). This group of interviewees served as a valuable source of information regarding the life trajectories and the societal contexts of the insurgents' choices with regard to disengagement. These interviews lasten spanned from an hour to around four hours. In addition, discussions with eyewitnesses of the Chechen wars $(n=22)$ were carried out to inquire about the general context of the political violence in the North Caucasus and its repercussions. The criterion for selecting interviewees of this second batch was their first-hand experience with the researched phenomenon. ${ }^{10}$

A third group of interviewees $(n=19)$ included leading Chechen and Russian journalists, political analysts, human rights activists, and scholars with first-hand experience with the researched phenomenon. ${ }^{11}$ These interviews spanned from an hour to

10 These interviews were centered around the following questions: "Did your community have any contact with nationalist/jihadist insurgents during the 2000s - and why?", "What made insurgents hesitant/willing to return to their/your communities?", "What categories of insurgents were more or less willing to disengage - and why?" During the interviews, our interlocutors were able to relatively easily identify nationalist and jihadist groups as they were knowledgeable of their dominant ideology, leadership, and goals. Although nationalist groups did extensively use Islamist symbols in an effort to legitimize their fight, our interlocutors were still able to tell apart the rhetoric and stylistic of insurgent groups from their ideology.

11 Those who allowed to be named include: Lema Tsjabajev (Chabayev), former press secretary of president Aslan Maskhadov at the Main Headquarters of the Chechen Army, currently a Prague-based journalist with the North Caucasus Service of the Radio Free Europe/Radio Liberty; Mairbek Vatchagaev, the former General Representative of the Chechen Republic of Ichkeria in Moscow, currently a nonresident fellow of the Jamestown Foundation; Mairbek Taramov, the Baku-based head of the Chechen Human Rights Centre; Usman Ferzauli, the Copenhagen-based 'minister of foreign affairs of the Chechen Republic of Ichkeria'; Abdulla Duduyev, the Moscow-based chief editor of the liberal Chechen journal 'Dosh'; Taus Serganova, a Grozny-based journalist with 'Dosh'; Ruslan Tachayev, a former high-ranking officer of the Chechen Army and currently a Vienna-based dissident and human rights activist; Huseyn Iskhanov, a former high-ranking officer of the Operative Directorate of the Main Headquarters of the Army 
around two hours. Direct questions were often asked during these interviews as to validate the accuracy of data provided by the first two groups of interviewees. In addition, seven interviews were conducted with predominantly Chechen human rights activists, experts, and former members of the Ichkerian elites, who explicitly requested anonymity in the article.

Most cases referred to in all interviews date to the period 2000-2007, while some interviewees addressed events spanning 1994-1996. Whenever interviewees expressed specific concerns with being videotaped or recorded, notes were taken either during or immediately after the interviews, depending on the interviewee's comfort level.

Interviews were supplemented with extensive ethnographic fieldwork, conducted by authors among eyewitnesses of both Chechen wars in the Chechen émigré communities based in Turkey and European countries, and the consultation of online documents from open sources. While these additional observations allowed for extensive triangulation of the interview material, the interviews themselves conducted with respondents from three different backgrounds helped to overcome the shortcomings of a limited sample and to compensate for potential biases, especially with regard to jihadists. Most of our ethnicChechen interviewees from ethno-nationalist groups self-identified as nationalists

of the Chechen Republic of Ichkeria, currently a Vienna-based activist and dissident; Andrei Babitsky, an award-winning journalist, formerly with Radio Free Europe/Radio Liberty, who covered both Chechen wars on the ground; Varvara Pakhomenko, an analyst of the International Crisis Group's Russian Justice Initiative who concentrates on Chechnya and the North Caucasus; Ivan Sukhov, a journalist with Kommerstant who covered the Second Chechen War on the ground; and Irina Gordienko, a journalist with Novaya gazeta specializing in the North Caucasus. We discussed various aspects of the violence in the North Caucasus, including the central themes of our article, with Tanya Lokshina of the Moscow branch of the Human Rights Watch and Svetlana Gannushkina of the Memorial human rights organization. In addition, in the period of 2007-2016, we carried out discussions with around two dozen predominantly Russian specialists who provided subject-matter expertise on the political violence in this North Caucasian republic. These specialists have included, among others, Ekaterina Sokirianskaia, the head of the Europe and Central Asia department of the International Crisis Group and a former officer of Memorial based in Chechnya and Ingushetia, and Alexander Cherkasov, a leading officer of Memorial specializing on Chechnya. 
("Ichkerians" in their vocabulary) as opposed to "radicals", "extremists", "fanatics", "Salafis" or "Wahhabis." They tended to downplay the salience of the nationalist-Islamist cleavage in the war-torn Chechen society in an attempt to portray the Chechens as a unique and indivisible people. Some sought to disqualify the emergence and functioning of jihadist groups as the "work of Arabs, Russian secret services, and other non-Chechens."

Since desertion, capitulation, and defection are considered demeaning in the honorcentered Chechen society with its strongly embedded codes of masculinity and warrior ethos, some Chechen respondents often hesitated to admit that their fellow Ichkerians were more susceptible to pressures to disengage than their Islamist counterparts. Even against the backdrop of such bias, our respondents self-identifying as nationalists provided in their testimonies sufficient evidence for our core claims. By and large, the interviews across the three discussed categories exhibited remarkable consistency.

\section{External pressure and capacity to resist}

Interviews demonstrate that individuals who joined armed units in the name of establishing an independent Chechen state were considerably more susceptible to external pressures to disengage than individuals who joined jamaats, i.e. jihadist groups. A common and recurring theme in the explanations provided by self-declared nationalist or patriot interviewees evolved around the notion of Islamists being 'religious fanatics' who, unlike nationalist fighters, rarely cared about their earthy concerns. According to one such interviewee, 'Wahhabites only cared about jannat [heaven], and whether their relatives

12 Interviews with Taramov and Iskhanov. 
could be killed by kadyrovtsy or not played little role in their considerations.' ${ }^{13}$ In fact, one of the most telling examples was the use of violence or threat thereof against insurgents' relatives, a practice frequently deployed by the Russian military's Chechen proxiesknown as kadyrovtsy - in the first half of the 2000s.

A number of Chechen insurgents, particularly high-ranking insurgent leaders, saw their relatives being abducted en masse by incumbent forces in waves of 'forced disappearances' that were commonplace in Chechnya during the researched period (Human Rights Watch 2001; Gilligan 2010). These relatives were threatened with murder one by one unless insurgents capitulated (Souleimanov 2015a). Facing this immense pressure, many nationalist insurgents submitted to the authorities.

Emblematic examples involved Turpal-Ali Atgeriyev, Deputy Prime Minister and National Security Minister serving in Chechnya's separatist government and Magomed Khambiyev, Chechnya's Minister of Defence and right-hand man of secularly minded President Aslan Maskhadov. Both nationalist leaders ultimately chose to abandon the struggle in order to save the lives of dozens of their captured relatives. Commenting on Khambiyev's capitulation, a contemporary report by Memorial-a prominent Russian human rights organization-asserted that:

Given the situation that had developed surrounding him, his family and the dozens or even hundreds of both close and distant relatives, Khambiyev had no other choice [...]. A different choice on his part would have been incomprehensible and unacceptable to the Chechen public - buying his 
own freedom with the freedom and lives of relatives would mean the breaking of unwritten laws and codes of conduct (Memorial 2004).

As acknowledged by Memorial, social milieu was an important factor prompting Khambiyev's capitulation. A refusal to submit, resulting in the death of one's relatives, would be unacceptable in Chechen public opinion.

While public opinion, entrenched in local customary law (adat), was salient for nationalist insurgents, jihadists openly decried it as they advocated for the complete eradication of what they considered to be non-Islamic heresy. Faced with the immense pressure of their captured relatives being threatened with murder, many jihadists chose to stand their ground and sacrifice their relatives' lives because, as one interviewee put it, 'this would turn their relatives into shahids [martyrs]. ${ }^{14}$ Indeed, for many jihadists, sacrificing their relatives for a divine cause was thought to account for ishtishhad, i.e. martyrdom, as it would ensure eternal life for their unjustly murdered relatives.

Another reason for many nationalistic Chechen insurgents to seek individual disengagement was what appeared to be the impossibility of victory in armed conflict. In fact, as early as in the early 2000s, the backbone of the Chechen Army was broken by heavy fighting in the capital city Grozny and its surroundings. ${ }^{15}$ During the advance, the Russian Army pushed the remnants of separatist groups into isolated mountainous parts of southern Chechnya, thereby draining the insurgency of its local social base. At that time, nationalist insurgents increasingly realized that the war was irreversibly lost. To many of them, the

\footnotetext{
14 Interview with 'Idris,' a relative of an ex-insurgent.

15 Within less than six months, the Chechen Army lost thousands of men and its elite forces were destroyed.
} 
prospect of waging a war without the slightest chance of military victory or the opportunity to deliver a sizable blow to the Russian Army that would prompt its withdrawal from Chechnya was no longer appealing.

Against the backdrop of mounting zachistki that swept Chechnya, and the humanitarian crisis that hit the local population, many nationalist insurgents were determined to return to their families to provide them with basic protection. As a relative of a former insurgent described:

Many [Chechen insurgents] understood back in mid-2000, that the war was all but over. In that situation, there were two ways to go: either continue fighting and sacrifice your life and the lives of your kin sooner or later, or to seek some form of peaceful life. Many have opted for the latter, and given the overall context in the republic, we can't blame them [for that]. ${ }^{16}$

The superior motive of saving the shrinking Chechen population from annihilation-a prospect that allegedly loomed in the early 2000 s as a possible consequence of the Chechens' continued resistance — and the ongoing use of indiscriminate violence by Russian forces were frequently referenced in the testimonies of former insurgents. According to interviewees, the one million-strong Chechen nation had no choice but to submit, however adverse and demeaning the repercussions, in order to survive in the face of Russia's superior size and seemingly limitless military and economic resources. ${ }^{17}$ 'The

\footnotetext{
16 Interview with 'Aslan.'

17 Interviews with former Chechen insurgents, their relatives and eyewitness of the Second Chechen War.
} 
main task [of the Chechen people] at that [historical] moment was to survive [glavnaya zadacha - perezhit']. ${ }^{, 18}$ Nationalist insurgents therefore viewed their abandonment of armed struggle as a lesser evil compared to the perils of continued resistance. However noble their steadfast resistance to the Russian occupation, 'it would soon lead to their [Chechens'] annihilation from the surface of the earth ${ }^{19}$, as stated by a former insurgent. The argument therefore posited that, 'taking into consideration the realities of the day, it was absolutely indispensable for us to pull out of the war, get back to normal life $[\ldots]$ and give birth to children. ${ }^{20}$

The likelihood of military victory was, however, not the primary reason for jihadists to either continue or abandon the struggle. Interviewees were in agreement over the fact that jihadists were less driven to fight by the prospect of victory than by the process of armed struggle (jihad) itself. ${ }^{21}$ Former jihadists, while acknowledging the presence of a number of factors - such as revenge, patriotism, and personal frustration-motivating individual jihadists to fight, pointed to the notion of jihad as the primary and decisive force behind their armed struggle. According to one of them, 'for such men... even if they failed to retaliate, achieve independence for Chechnya or create an Islamic state in Chechnya, if they lost their lives in the jihad, they would still consider themselves winners. That is what eventually mattered to them. ${ }^{22}$

\footnotetext{
18 Interview with ,Idris.

19 Interview with 'Magomed.'

20 Interview with 'Magomed.'

21 Interviews with former insurgents, both nationalists and jihadists, their close friends, and relatives. This idea relates to Wood's ,pleasure of agency“, which is not unique to Islamists (Wood 2003), and which goes beyond ,instrumental reasoning“ (Gutierrez and Wood 2014, 220 221).

22 Interview with 'Mairbek,' a former jihadist.
} 
In fact, participation in the armed conflict and the subsequent likelihood of selfsacrifice along the divine path appears to have been of greater importance for jihadists than the declared goal of establishing an Islamic state in Chechnya, the North Caucasus, or globally. As a result, waging jihad - regardless of its ultimate outcome - therefore became a self-perpetuating and self-vindicating process. Unlike jihadists, for most nationalists, the establishment of an independent Chechnya was their ultimate goal as opposed to selfsacrifice in the name of God or the nation. ${ }^{23}$

In addition, while Chechen nationalists considered themselves as part of the Chechen nation and their armed fight as dedicated to and shaped by the interests of the Chechen nation, jihadists rather conceived of themselves as part of a global Muslim community of fellow believers, known as umma. The well-being and ultimate interests of umma were thus considered the jihadists' principal goal. At the same time, the particular interests of the Chechen nation were disavowed often along with the very notion of Chechenness as essentially non-Islamic and therefore heretical.

Commenting on his experience with jihadists, a former insurgent summarized the attitudes towards the jihadists shared by many nationalist ex-insurgents and ordinary Chechens in that 'jihadists cared little, if at all, about the Chechens. All that they cared about was jihad and jennet [paradise]. ${ }^{24}$ This view was largely supported across all categories of interviewees. As encapsulated by Andrei Babitsky, 'for nationalists, the notions of native soil and shared blood - including family, clan, and people - were decisive.

23 Exceptions were nationalist insurgents who were driven by their desire for personal retaliation, as part of the local tradition of blood revenge. According to interviewees, such individuals were often willing to sacrifice their lives to avenge their relative's death, fatal injury, or humiliation. Importantly, avengers, as interviewees usually referred to them, were more likely to be recruited into jihadist than nationalist groups.

$24 \quad$ Interview with 'Ali,' a former nationalist insurgent. 
This is why they were relatively inclined to strike deals with the [pro-Moscow] authorities, and the locals' attitude to them didn't really change as they [nationalists] often did this to save their relatives from extermination. This wasn't considered an act of treason. Whereas for Salafis, God was above all [...], survival was thought of in strictly spiritual terms - to get to heaven. ${ }^{25}$

Interviewees also suggest that nationalists were overall significantly more susceptible than jihadists to other types of pressure such as heavy casualties and significant wartime hardships, scarcity of food and medicine, and the incessant diseases that regularly plagued insurgents. Interviewees generally attributed these characteristics to jihadists' devotion to ideology, referred to by some as 'fanaticism,' and to the subsequent fatalism and self-restraint exhibited by religiously minded insurgents. ${ }^{26}$

To summarize the ideas presented in this section, interviews revealed that jihadists were considerably more exposed to ideology than nationalists, and Salafi-jihadist ideology implied a normative and emotional commitment rather than an instrumental use of ideology, as more commonly practiced by nationalists. The level of ideological indoctrination among jihadists was so overwhelming as to render marginal the various pressures that typically pave the way for individual disengagement, such as physical survival, the unlikelihood of military victory, wartime hardships, and other related factors. Jihadists' willingness to accept self-sacrifice (ishtishhad) on the path of divine struggle (jihad) shaped by Salafi-jihadist dogma made these militants resistant to such pressures.

$25 \quad$ Interview with Andrei Babitsky, May 2016.

26 Interviews with former nationalist and jihadist insurgents. 


\section{Use of violence and individual exposure}

From 1999 to 2007, Russian authorities declared seven successive amnesties to lay the legal foundations for fighters to return to peaceful civilian life (Souleimanov 2006). Amnesties were usually accompanied by the federal authorities' practice of screening the identities of the insurgents who sought disengagement either collectively or individually. Those suspected of committing the felony of terrorism were rarely pardoned, if at all. ${ }^{27}$

In Chechnya, jihadist groups were on average more likely to be responsible for committing highly lethal attacks, particularly against civilians, than their nationalist counterparts (McCartan, Masselli, Rey and Rusnak 2008). In fact, while terrorist attacks were nearly non-existent during the First Chechen War-when the local insurgency was led mainly by nationalist groups - the jihadist-dominated Chechen insurgency began to embrace increasingly lethal terrorist attacks beginning in the early 2000s (Toft and Zhukov $2015,228)$. Jihadists were therefore less inclined to disengage than nationalists because, as stated by a former insurgent, 'to lay down arms [and return to peaceful life], you have to have some basic certainty that your life would be spared if, or rather when, they [the authorities] discover you.' 28

The increasing deployment of kadyrovtsy paramilitaries in counterinsurgency operations contributed to the strengthening of incumbent control over the populace and territory. Given their familiarity with the local social niveau, kadyrovtsy and their relatives were able to keep an eye on developments on the ground and to access quality intelligence

27 What usually awaited apprehended jihadists was life imprisonment accompanied by severe humiliation and torture or outright extrajudicial executions.

28 Interview with 'Umar,' a former nationalist insurgent. 
on the insurgents, their social connections, modus operandi, etc. ${ }^{29}$ As a result, authorities have grown increasingly aware of the insurgents' identities, and it is currently very rare for authorities not to know the identities of recruits for prolonged periods (Souleimanov 2015a; Souleimanov and Aliyev 2015). As a result, counterinsurgency forces exerted widespread violence against insurgents' relatives in order to force insurgents into capitulation or as a means of retribution. Those insurgents — both jihadist and nationalist — who initially sought to conceal their identities in an effort to salvage their relatives eventually lost the rationale to do so.

The deployment of kin-on-kin violence perpetrated by kadyrovtsy had far-reaching effects. While on the one hand an additional impetus for nationalist insurgents to seek disengagement, it provided, on the other hand, for a certain sort of ideological 'casting' of would-be recruits into the insurgent groups. In fact, from the early 2000s on, religiously minded individuals seeking membership in insurgent units decidedly outnumbered secularly motivated individuals. Interviewees have also pointed out, as a consequence of this development, nationalistically minded individuals, avoided entering insurgent units out of concern for the safety of their relatives. ${ }^{30}$ This in turn further reinforced the 'jihadization' of Chechen insurgent groups.

Over time, and owing to an increased capacity of kadyrovtsy, the lethality rates in the ranks of Chechen insurgent units grew. While these units numbered hundreds in the first half of the 2000s, they plummeted in the second half of the 2000s and later on, numbering

29 Chechnya's demographics and geography also contributed to this. Chechnya is a republic of around 17,000 square kilometers, with episodic insurgent activity being confined to around one fourth of the republic's territory.

30 Interviews with former nationalist insurgents and eyewitnesses of the Second Chechen War. 
less than a hundred nowadays, all of them hiding in the harsh conditions of mountainous Chechnya. ${ }^{31}$ In a similar vein, the insurgents' social base was shattered. Due to immense control and the risk of retribution at the hands of kadyrovtsy, many Chechens previously sympathetic to insurgents ultimately chose to deny support to them (Souleimanov and Aliyev 2015). As a result, as an interviewee put it, '[jihadist] fighters are in fact kamikaze [suicides] as they have no other future than to submit to either a bullet, hunger, injury or cold. ${ }^{32}$

Jihadists, however, have managed to turn their vulnerability into a virtue through their profound disdain for death, wartime hardship, and their courage and devotion to their cause. Given their apparent reconciliation with their fate, jihadists rarely sought to hide their identities. On the contrary, they rather made every possible effort to reveal their identities in order to 'strike fear into the hearts of kadyrovtsy and show [notwithstanding anything] they were not intimidated and were determined to fight until the very end. ${ }^{33}$ This was also pointed out by Lema Chabayev, jihadists usually did not conceal their identities because 'unlike nationalists, jihadists never counted on the possibility to disengage [at some point of their lives] and they rarely cared about the repercussions of their attacks amidst the civilian population. On the one hand, they expected no mercy. In fact, they strongly believed they were going to find jannah [heaven] [which was their ultimate goal]. ${ }^{34}$

In summary, in comparison to nationalists, jihadists tended to use more lethal indiscriminate violence, had a higher acceptance of self-sacrifice derived from ideological

31 Authors' discussions with Russian and Chechen specialists, 2015-2016.

32 Interview with 'Shamil,' a former jihadist.

33 Interview with a Chechen political scientist, June 2014.

$34 \quad$ Interview with Lema Chabayev, January 2014. 
indoctrination, and cared consequently less about concealing their identities. This, in turn, made disengagement a less viable course of action for jihadists, when compared to nationalists, due to their fear of being exposed to severe punishment at the hands of the incumbent.

\section{Social bonds and group cohesiveness}

Unlike nationalists, jihadists in Chechnya have been a relatively socially isolated group due to their severed ties to the world beyond their armed group and their strong group identity. Since Salafi-jihadist ideology began to spread in Chechnya in the 1990s, its local advocates identified themselves in stark opposition to the local tradition. The latter, embodied by the local customary law, adat, and Sufi Islam - an eclectic form of 'people's Islam' considered to be heresy by Salafis - has historically shaped Chechnya's social fabric.

Mounting theological tensions between proponents of the two competing camps led to armed clashes between jihadist revolutionaries on the one hand and 'traditionalists' on the other hand, beginning in the 1990s and peaking during the interwar period (Souleimanov 2005). Vakhid Akaev, a prominent Chechen historian, recalls the 'harsh arguments between children and parents' in Chechnya during the 1990s, when Salafi-jihadi ideology asserted itself in the country and the gradual emersion of jamaats. During this period, '[Salafi] children provoked their [traditionalist] fathers into such conflicts' because 'young men [were] being instructed by an adherent of "pure Islam": 
... do not revere sheikhs and ustazes [murshids], do not revere the elderly! A question immediately arises: why is it forbidden to revere the elderly? The answer is simple: because it is tantamount to creating an equal to Allah (Akaev 2006, 19).

As a result, jihadists were viewed by the local population as 'Arabized Chechens,' 'sectarians', and advocates of 'Wahhabism' - an alien ideology to the Chechens and their age-old customs - and were in turn stripped of their 'Chechenness' and disowned by their families and communities. This ultimately led to their loss of a significant amount of popular support, which stood in contrast to nationalists who retained strong social contacts, including popular support and community networks. As a Chechen political scientist put it, 'being wahhabi [vakhkhabit] goes against all what constitutes the essence of Chechenness: respect to father, elderly people, Chechen tradition and values [...]. You can't be a Chechen and a Wahhabi at the same time. ${ }^{35}$

While jihadists identified the imposition of Islamic rule and the establishment of a Salafi theocracy as the main premise of their struggle, the nationalists' goal of establishing an independent Chechnya resonated deeply with the local population. Accordingly, wouldbe recruits into jihadist groups - regardless of their motive for joining such groups or the degree to which they embraced a group's ideology (Souleimanov 2015b)—were usually shunned by their families and home communities. With the noteworthy exception of Salafiminded Chechens who formed a minority in the local population, many ordinary Chechens considered their cause unjust. ${ }^{36}$ In line with this tense relationship, jihadists have relied on 
funding from foreign donors, in contrast to the nationalist groups (see also Toft and Zhukov 2015).

Having severed ties with their families and communities, jihadists found themselves in jamaats that increasingly resembled religious cults, with members of such groups considering each other as family, with the group as the only social group available to them. In addition, as Salafi-jihadi dogma required individuals to disown anyone, even family members, considered to be hypocrite and apostate, jihadists had an additional ideological reason to legitimize their estrangement from their kin and local communities. Jihadists also had to strip themselves of any non-Islamic form of self-identification, such as race, class, ethnicity, kinship, and community, since the Salafi-jihadi dogma recognizes religion as the single legitimate source of identity. According to a Chechen political scientist, having embraced Salafi-jihadism, 'they [fighters] ceased to be Chechens.' ${ }^{37}$ Many neighbors of families whose members joined a jihadi group in the interwar period and during the subsequent years admitted that while families initially sought to keep contact to youngsters as they saw their obsession to be temporary, the latter soon distanced themselves from their relatives as they saw their 'Russified' way of life, along with the elements of 'pagan' Sufi tradition, to violate the foundations of 'true' Islam. Often failing to convert their conservative relatives to 'true' Islam, jihadist expressed explicit disrespect to the local tradition which in many cases led their families to disown them, a painful act given the strength of patriarchal values in Chechen society. Having broken up once, it was extremely difficult for jihadist to be accepted back into their families and clans, with interpersonal and cultural distance between jihadist and their families strengthening over years.

37 Interview with a Chechen political scientist, June 2014. 
As acknowledged by a former jihadist, after spending years in a jihadist group with all links to the outside world severed, the jamaat brotherhood becomes an importantoften the only_ part of a jihadist's identity. His fellow jihadists become the insurgent's only social contacts and jihad the only meaning in his life. ${ }^{38}$ 'Salafi brotherhoods replaced families [for the members of jihadist groups], they were the backbone of the universe to them as they severed ties to their families and communities whom they [jihadists] considered infidel. ${ }^{39}$ Against this backdrop, leaving a jamaat would pose an immense challenge to the very core of one's identity, unlike the prospect of leaving a nationalist group, where insurgents retained deep connections to their families, home communities, and other social networks. ${ }^{40}$ In fact, nationalists' membership in their groups was usually loose, unlike the jihadists'. Nationalists went in and out, rotating months 'in combat' with months in their native villages.

In summary, the level of social bonding to the outside world and the strength of group identity are key determinants for disengagement processes in Chechnya. As suggested by interviewees, even those jihadists inclined to weigh the costs of prospective disengagement had nowhere to return to as they had been disowned by their families and were considered outcasts by local communities. ${ }^{41}$ Psychologically speaking, severing ties with a jihadist group required immense courage and motivation, which many individuals lacked. Unlike nationalists, who often retained various layers of identity, including ethnic, religious, clan,

\footnotetext{
$38 \quad$ Interview with 'Usman.'

39 Interview with Babitsky.

40 Over time, this isolation from the outside world encouraged jihadists to be less discriminatory in their selection of targets and lethal use of violence, as described in the previous section. They did not have to take into consideration the concerns of the local population that largely disapproved of these tactics. Jihadists' inclination to use such force therefore antagonized the local population even further.

41 Interviews with former jihadists and eyewitnesses of the Second Chechen War.
} 
territorial, and class-based forms of identity, jihadists' identity was constructed around their ideology and based more clearly on their membership in a jamaat. As a result, contrary to the case of nationalists, disengagement among jihadists has been an extremely rare phenomenon.

\section{Conclusion}

This article set up to provide an empirical account of how militants belonging to two key categories of organizations — nationalist and Islamist — disengage from armed struggle. We examined whether group-level militant disengagement would be driven by four distinct mechanisms: the capacity to resist to external pressure, the methods of using violence, social bonds, and group cohesiveness.

Empirical examination of qualitative data related to group-level disengagement in Russia's Chechen Republic demonstrates that rather precarious levels of ideological commitment among nationalist militants markedly distinguishes them from jihadists, who consistently show particularly high levels of ideological adherence. The differential ideological setup of the two groups has consequences for the process of disengagement: First, Chechen Salafi-jihadists, as compared to nationalists, show relatively low susceptibility to pressures such as paramilitary violence against their relatives, a bleak military outlook and wartime hardship. Second, in contrast to jihadists, who often resorted to indiscriminate forms of violence, nationalists were less likely to target civilians and members of their fellow ethnic group, and preferred anonymity in order to protect their families, which made disengagement a more viable option for them. And third, preserving close social bonds with family, friends, and the local population allowed nationalist 
militants to find a way back to civilian life, as opposed to Chechen jihadists, who purposefully severed links with their kin and constructed their identity around close-knit brotherhoods of like-minded people. As a result, nationalist militants have been the largest group of Chechen militants to have voluntarily disengaged from armed struggle since the start of the conflict in Chechnya in the 1990s. Salafi-jihadist militants stand in stark contrast to nationalists. Only a small number of them participated in individual (or collective) disengagement during the observed period.

Although these empirical findings are case-specific to Chechnya, they demonstrate that the pathways to disengagement are greatly influenced by the ideological profiles of militant organizations. Specifically, we show that ideology has wide-ranging effects on individuals' wartime behavior. After a long-standing debate about the role of ideology for the functioning of militant groups and the motivation of individual combatants in the peace and conflict literature (Collier and Hoeffler 2004; Gutierrez and Wood 2014; Ugarriza and Craig 2013), our analysis emphasizes the importance of ideology also for disengagement processes. Whether armed groups use ideology for merely instrumental reasons or, more extensively, as part of their modus vivendi shapes the group-level disengagement for their members.

Since this article both draws from and builds on the contextual richness of a single case study, it does not make explicit claims to generalization. We are thus modest in terms of this article's findings as we are cognizant of the natural limitations of ethnographic research in general and the limited (but still significant given our interlocutors' security concerns) pool of our interlocutors willing to share their experiences about this enormously sensitive subject matter. Nevertheless, to the best of our knowledge, this is the first study 
to date to suggest a link between ideology (Islamism and jihadism) and disengagement. No such claim has been made in the extant literature, nether theoretically nor empirically.

In fact, the similarity of modus operandi and modus vivendi of nationalist and Islamist groups across cases suggests that this study's findings may hold more universally. Also, the idea that disengagement processes are not only driven by individual-level determinants, but also depend on the type of group and the related use of ideology, may be applied more broadly. However, the scope of the presented argument is limited by the fact that militant organizations, including Islamist groups, are often the result of local alliances (Ahmad 2015; Christia 2012; Sinno 2009), and their ideological core may thus be less clearly defined than in the Chechen case.

Future research might look at other settings of co-existing Islamist and nationalist groups to test our empirical argument. Cases with large use of indiscriminate violence by nationalists or strong ties between Islamist groups and local populations may provide particularly promising testing grounds. More generally speaking, the evidence base for research on disengagement, and especially group-level disengagement from Islamist groups, needs to be improved. Data on demobilized fighters from different countries (for example European jihadists who return to their home country) should be integrated to allow for more systematic comparisons. In practice, understanding the role of militant organizations' typology may be crucial not only for the effectiveness of micro-level individual disengagement programs, but also for broader DDR processes, de-radicalization programs and peacebuilding efforts. 


\section{References}

Ahmad, Aisha. 2015. "The Security Bazaar: Business Interests and Islamist Power in Civil War Somalia.” International Security 39 (3): 89-117.

Alexander, John. 2012. “'Decomposing' an Insurgency.“ The RUSI Journal 157:48-54.

Akaev, Vakhid. December 12, 2006. Kto i zachem eksportiroval vakhkhabism v Chechnyu. Agentstvo natsional'nykh novostey, [Who and Why Exported Hahhabism to Chechnya. Agency of National News.] <http://www.annews.ru/news/detail.php?ID=60968> (2014, January 1).

Alonso, Rogelio. 2011. "Why Do Terrorists Stop? Analyzing Why ETA Members Abandon or Continue with Terrorism.“ Studies in Conflict \& Terrorism, 34:696-716.

Altier, Mary Beth, Christian N. Thoroughgood, and John G. Horgan. "Turning Away from Terrorism. Lessons from Psychology, Sociology, and Criminology.” Journal of Peace Research 51, no. 5 (2014): 647-61.

Asal, Victor H., R. Karl Rethemeyer, Ian Anderson, Allyson Stein, Jeffrey Rizzo, and Matthew Rozea. “The Softest of Targets: A Study on Terrorist Target Selection.” Journal of Applied Security Research 4, no. 3 (2009): 258-78.

Atran, Scott, Hammad Sheikh, and Angel Gomez. 2014. "Devoted Actors Sacrifice for Close Comrades and Sacred Cause.” Proceedings of the National Academy of Sciences 111 (50): 17702-3.

Baines, Erin, Nadine Harris, and Kyle McCleery. 2010. "'Death Is Painful So It Is Better to Be Holding a Gun' “ Conflict, Security \& Development 10:625-645.

Barr, Nathaniel, and Bridget Moreng. 2016. „The Graveyard of Caliphates. The Failure of ISIS in Afghanistan." Foreign Affairs, January 13.

Bartov, Omer. 1992. Hitler's Army. New York: Oxford University Press.

Bearman, Peter S. 1991. "Desertion as Localism: Army Unit Solidarity and Group Norms in the U.S. Civil War." Social Forces 70 (2): 321-42.

Berman, Eli. 2011. Radical, Religious, and Violent: The New Economics of Terrorism. Boston: MIT Press. Bjørgo, Tore, and John Horgan, eds. 2009. Leaving Terrorism Behind: Individual and Collective Disengagement. London: Routledge. 
Bjørgo, Tore. 2011. "Dreams and Disillusionment: Engagement in and Disengagement from Militant Extremist Groups. “ Crime Law Soc Change 55:277-285.

Bloom, Mia. 2004. Dying to Kill: The Global Phenomenon of Suicide Terrorism. New York: Columbia University Press.

Carter, Ashton, John Deutch, and Philip Zelikow. 1998. “Catastrophic Terrorism.“ Foreign Affairs 77:8094.

Chalk, Peter. 1999. "The Evolving Dynamic of Terrorism in the 1990s.“ Australian Journal of International Affairs 53:151-167.

Christia, Fotini. 2012. Alliance Formation in Civil Wars. Cambridge: Cambridge University Press.

Cohen, Dara Kay. 2013. "Explaining Rape during Civil War: Cross-National Evidence (1980-2009)." American Political Science Review 107 (03): 461-77.

Collier, Paul, and Anke Hoeffler. 2004. "Greed and Grievance in Civil War.” Oxford Economic Papers 56 (4): 563-95.

Costa, Dora L., and Matthew E. Kahn. 2008. Heroes and Cowards: The Social Face of War. Princeton: Princeton University Press.

Cronin, Audrey. 2009. How Terrorism Ends. Understanding the Decline and Demise of Terrorist Campaigns. Princeton, NJ: Princeton University Press.

Cunningham, Kathleen Gallagher. 2014. Inside the Politics of Self-Determination. Oxford: Oxford University Press.

Dalgaard-Nielsen, Anja. 2010. "Violent Radicalization in Europe." Studies in Conflict \& Terrorism $33: 797-814$.

Dalgaard-Nielsen, Anja. 2013. "Promoting Exit from Violent Extremism: Themes and Approaches." Studies in Conflict \& Terrorism 36:99-115.

Demant, Froukje, and Beatrice de Graaf. 2010. "How to Counter Radical Narratives: Dutch Deradicalization Policy in the Case of Moluccan and Islamic Radicals. “ Studies in Conflict \& Terrorism 33:408-428. 
Della Porta, Donatella. 2009. "Leaving Underground Organizations: a Sociological Analysis of the Italian case.“ In Leaving Terrorism Behind. Individual and Collective Disengagement, eds. Tore Bjørgo and John Horgan. London: Routledge.

de Vries, Hugo, and Nikkie Wiegink. 2011. "Breaking up and Going Home? Contesting Two Assumptions in the Demobilization and Reintegration of Former Combatants.“ International Peacekeeping 18:3851.

Dingley, James. 2001. “The Bombing of Omagh, 15 August 1998: the Bombers, Their Tactics, Strategy, and Purpose Behind the Incident.“ Studies in Conflict \& Terrorism 24: 451-465.

Doosje, Bertjan, Fathali M. Moghaddam, Arie W. Kruglanski, Arjan de Wolf, Liesbeth Mann, and Allard R. Feddes. "Terrorism, Radicalization and de-Radicalization." Current Opinion in Psychology, Intergroup relations, 11 (2016): 79-84.

Drake, C. J. M. “The Role of Ideology in Terrorists' Target Selection.” Terrorism and Political Violence 10, no. 2 (1998): 53-85.

Florez-Morris, Mauricio. 2010. “Why Some Colombian Guerrilla Members Stayed in the Movement Until Demobilization.“ Terrorism and Political Violence 22:216-241.

Gilligan, Emma. 2010. Terror in Chechnya: Russia and the Tragedy of Civilians in War. Princeton, NJ: Princeton University Press.

Gilmore, Margaret. 2009. "No Way Back? Examining the Background and Response to the Rise of Dissident Terrorist Activity in Northern Ireland.“ The RUSI Journal 154:50-55.

Goodwin, Jeff. “A Theory of Categorical Terrorism.” Social Forces 84, no. 4 (2006): 2027-46.

Gutierrez, Francisco, and Elisabeth Jean Wood. 2014. "Ideology in Civil War Instrumental Adoption and beyond." Journal of Peace Research 51 (2): 213-26.

Hafez, Mohammed. 2008. "Radicalization in the Persian Gulf: Assessing the Potential of Islamist Militancy in Saudi Arabia and Yemen." Dynamics of Asymmetric Conflict: Pathways toward Terrorism and Genocide 1:6-24.

Hahn, Gordon. 2008. 'The Jihadi Insurgency and the Russian Counterinsurgency in the North Caucasus.“ Post-Soviet Affairs 24: 1-39. 
Hall, John A., and Siniša Malešević, eds. 2013. Nationalism and War. Cambridge: Cambridge University Press.

Hanasz, Paula. 2012. “Appeasing 'Upset Brothers': an Introduction to the Afghanistan Peace and Reintegration Program.“ Australian Journal of International Affairs 66:155-168.

Harris, Daniel J., Pete Simi, and Gina Ligon. 2016. "Reporting Practices of Journal Articles That Include Interviews with Extremists.” Studies in Conflict \& Terrorism 39 (7-8): 602-16.

Hegghammer, Thomas. 2009. "The Ideological Hybridization of Jihadi Groups." Current Trends in Islamist Ideology 9:26-45.

Horgan, John. 2009. Walking Away from Terrorism: Accounts of Disengagement from Radical and Extremist Movements. London: Routledge.

Horgan, John, and Kurt Braddock. 2010. "Rehabilitating the Terrorists?: Challenges in Assessing the Effectiveness of De-radicalization Programs.“ Terrorism and Political Violence 22:267-291.

Human Rights Watch. March 1, 2001. The 'Dirty War' in Chechnya: Forces Disappearances, Torture, and Summary. <https://www.hrw.org/report/2001/03/01/dirty-war-chechnya-forced-disappearancestorture-and-summary> (2015, September 24).

Hughes, James. 2007. Chechnya: From Nationalism to Jihad. Philadelphia, PA: University of Pennsylvania Press.

Jarman, Neil. 2004. "From War to Peace? Changing Patterns of Violence in Northern Ireland, 19902003.“ Terrorism and Political Violence 16:420-438.

Juergensmeyer, Mark. 1997. “Terror Mandated By God.“ Terrorism and Political Violence 9:16-23.

Jäger, Herbert, Gerhard Schmidtchen, and Lieselotte Süllwold. Lebenslaufanalysen. Opladen: Westdeutscher Verlag, 1981.

Kalyvas, Stathis N., and Matthew A. Kocher. 2007. “How 'Free' is Free Riding in Civil Wars?: Violence, Insurgency, and the Collective Action Problem.“ World Politics 59:177-216.

Kaplan, Oliver, and Enzo Nussio. 2016. "Explaining Recidivism of Ex-Combatants in Colombia.” Journal of Conflict Resolution, online first.

Kassimeris, George. 2011. "Why Greek Terrorists Give Up: Analyzing Individual Exit from the Revolutionary Organization 17 November.“ Studies in Conflict and Terrorism 34:556-571. 
Kavkaz Uzel. 2008. V Chechne sdalsya byvshii podchinennyi Salmana Raduyeva. Kavkaz uzel 14.10.2008.

Knight, Mark, and Alpaslan Özerdem. 2004. "Guns, Camps and Cash: Disarmament, Demobilization and Reinsertion of Former Combatants in Transitions from War to Peace." Journal of Peace Research 4:499-516.

Lyall, Jason. “Are Coethnics More Effective Counterinsurgents? Evidence from the Second Chechen War.“ American Political Science Review 104:1-20.

Marriage, Zoë. 2007. "Flip-flop Rebel, Dollar Soldier: Demobilisation in the Democratic Republic of Congo.“ Conflict, Security \& Development 7:281-309.

McCartan, Lisa M., Andrea Masselli, Michael Rey and Danielle Rusnak. 2008. "The Logic of Terrorist Target Choice: An Examination of Chechen Rebel Bombings from 1997-2003.“ Studies in Conflict and Terrorism 31:60-79.

McLauchlin, Theodore. 2014. "Desertion, Terrain, and Control of the Home Front in Civil Wars." Journal of Conflict Resolution 58 (8): 1419-44.

—. 2015. "Desertion and Collective Action in Civil Wars." International Studies Quarterly 59 (4): $669-79$.

Memorial. March 10, 2004. 'Dobrovolnaya sdacha' Magomeda Khambiyeva. [Voluntary surrender of Magomed Khambiyev]. <www.memo.ru/hr/hotpoints/caucas1/msg/2004/03/m13451.htm> (2013, September 24).

Moghadam, Assaf. 2012. "Failure and Disengagement in the Red Army Faction." Studies in Conflict \& Terrorism 35:156-181.

Muggah, Robert. 2005. "No Magic Bullet: A Critical Perspective on DDR and Weapons Reduction in Postconflict Contexts.“ The Round Table 94:239-252.

Mukhopadhyay, Dipali. 2009. "Disguised Warlordism and Combatanthood in Balkh: the Persistence of Informal Power in the Formal Afghan State.“ Conflict, Security \& Development 9:535-564.

Nesser, Petter. 2006. "Jihadism in Western Europe After the Invasion of Iraq." Studies in Conflict \& Terrorism 29:323-342.

News.ru. 2006. Kadyrovu pod ego lichnie garantii sdalis 49 chechenskikh boevikov. NEWS.RU 29.08.2006. 
Nussio, Enzo. 2012. La Vida Después de La Desmovilización. Percepciones, Emociones Y Estrategias de Exparamilitares En Colombia. Bogotá: Universidad de los Andes.

Nussio, Enzo, and Ben Oppenheim. 2014. "Anti-Social Capital in Former Members of Non-State Armed Groups: A Case Study of Colombia.” Studies in Conflict \& Terrorism 37 (12): 999-1023.

Oppenheim, Ben, Abbey Steele, Juan F. Vargas, and Michael Weintraub. 2015. "True Believers, Deserters, and Traitors. Who Leaves Insurgent Groups and Why." Journal of Conflict Resolution 59 (5): 794 823.

Parkinson, Sarah Elizabeth. 2013. “Organizing Rebellion: Rethinking High-Risk Mobilization and Social Networks in War.” American Political Science Review 107 (03): 418-32.

Piazza, James A. 2009. "Is Islamist Terrorism more Dangerous?: An Empirical Study of Group Ideology, Organization, and Goal Structure.“ Terrorism and Political Violence 21:62-88.

Pick, Thomas M., Anne Speckhard and Beatrice Jacuch, eds. 2009. Home-grown Terrorism. Amsterdam: Ios Press.

Quillen, Chris. 2002. "A Historical Analysis of Mass Casualty Bombers.“ Studies in Conflict and Terrorism 25:279-292.

Rabasa, Angel, Stacie Pettyjohn, Jeremy Ghez and Christopher Boucek. 2010. Deradicalizing Islamist Extremists. Santa Monica, CA: RAND.

RBK. 2004. V Chechne dobrovol`no sdalsia polevoi komandir S.Eldarov. 22.05.2004.

Ratelle, Jean-François, and Emil A. Souleimanov. 2016. "A Perfect Counterinsurgency? Making Sense of Moscow's Policy of Chechenisation," Europe-Asia Studies 68(8): 1287-1314.

Regnum. 2003. Chechnya: Byvshii boevik pomog predotvratit krupnie terakty v stolitse i krupnom raionnom tsentre respubliki. REGNUM 03.07.2003.

Reinares, Fernando. 2011. “Exit From Terrorism: A Qualitative Empirical Study on Disengagement and Deradicalization Among Members of ETA.“ Terrorism and Political Violence 23:780-803.

Rolston, Bill. 2007. "Demobilization and Reintegration of Ex-Combatants: the Irish Case in International Perspective.“ Social \& Legal Studies 16:259-280.

Russell, John. 2009. "The Geopolitics of Terrorism: Russia's Conflict with Islamic Extremism.“ Eurasian Geography and Economics 50:184-196. 
Sagramoso, Domitilla. 2012. “The Radicalisation of Islamic Salafi 'Jamaats' in the North Caucasus.“ Europe-Asia Studies 64:561-595.

Sinno, Abdulkader H. 2009. Organizations at War in Afghanistan and Beyond. Ithaca: Cornell University Press.

Souleimanov, Emil. 2005. "Chechnya, Wahhabism and the Invasion of Dagestan.“ Middle East Review of International Affairs 9:48-71.

Souleimanov, Emil. 2006. An Endless War: The Russian-Chechen Conflict in Perspective. Frankfurt am Main: Peter Lang.

Souleimanov, Emil. 2011. "The Caucasus Emirate: Genealogy of an Islamist Insurgency.“ Middle East Policy 18:155-168.

Souleimanov, Emil, and Huseyn Aliyev. 2014. The Individual Disengagement of Avengers, Nationalists, and Jihadists: Why Ex-militants Choose to Abandon Violence in the North Caucasus, Basingstoke: Palgrave Macmillan.

Souleimanov, Emil. 2014b. "Split Among North Caucasian Fighters in Syria." The Central Asia and Caucasus Analyst, February 7.

Souleimanov, Emil. 2015a. “An Ethnography of Counterinsurgency: Kadyrovtsy and Russia’s Policy of Chechenization." Post-Soviet Affairs 31:91-114.

Souleimanov, Emil. 2015b. “'Jihad or Security?' Understanding the Jihadization of Chechen Insurgency through Recruitment into Jihadist Units.“ Journal of Balkan and Near Eastern Studies 17:86-105.

Souleimanov, Emil, and Huseyn Aliyev. 2015. “Asymmetry of Values, Indigenous Forces, and Incumbent Success in Counterinsurgency: Evidence from Chechnya.“ Journal of Strategic Studies 38:678-703. Staniland, Paul. "Between a Rock and a Hard Place Insurgent Fratricide, Ethnic Defection, and the Rise of Pro-State Paramilitaries.” Journal of Conflict Resolution 56, no. 1 (2012): 16-40.

Stern, Jessica. January/February 2010. "Mind over Martyr: How to Deradicalize Islamist Extremists.“ Foreign Affairs.

Stern, Jessica. 1999. The Ultimate Terrorists. Cambridge, MA: Harvard University Press.

Theidon, Kimberly. 2007. “Transitional Subjects: The Disarmament, Demobilization and Reintegration of Former Combatants in Colombia.“ The International Journal of Transitional Justice 1:66-90. 
Themnér, Anders. 2013. “A Leap of Faith: When and How Ex-Combatants Resort to Violence." Security Studies 22:295-329.

Tilly, Charles. 1978. From Mobilization to Revolution. London: McGraw-Hill.

Toft, Monica D., and Yuri M. Zhukov. 2015. "Islamists and Nationalists: Rebel Motivation and Counterinsurgency in Russia's North Caucasus.“ American Political Science Review 109:222-238.

Ugarriza, Juan E., and Matthew J. Craig. 2013. “The Relevance of Ideology to Contemporary Armed Conflicts.” Journal of Conflict Resolution 57 (3): 445-77.

Walter, Barbara F. 1999. "Designing Transitions from Civil War. Demobilization, Democratization, and Commitments to Peace.“ International Security 24:127-155.

Wood, Elisabeth Jean. 2003. Insurgent Collective Action and Civil War in El Salvador. Cambridge: Cambridge University Press.

Villegas, Cristina. 2009. "Motives for the Enlistment and Demobilization of Illegal Armed Combatants in Colombia." Peace and Conflict 15:263-280. 